\title{
IMPACTS OF CITRUS PULP ADDITION AND WILTING ON ELEPHANT GRASS SILAGE QUALITY
}

\author{
IMPACTO DA ADIÇÃO DE POLPA CITRÍCA E DO EMURCHECIMENTO NA \\ QUALIDADE DA SILAGEM DE CAPIM-ELEFANTE
}

\author{
Raphael dos Santos GOMES ${ }^{1}$; João Carlos de Carvalho ALMEIDA ${ }^{2}$; \\ Jailton da Costa CARNEIRO ${ }^{3}$; Flavio Henrique Vidal AZEVEDO ${ }^{1}$; Fábio Nunes LISTA $^{4}$; \\ Ana Cristina Wyllie ELYAS ${ }^{2}$; Tadeu Silva de OLIVEIRA ${ }^{1}$ \\ 1. Universidade Estadual do Norte Fluminense Darcy Ribeiro, Programa de Pós-graduação em Ciência Animal, Campos dos \\ Goytacazes, RJ, Brazil. raphael_zootec@yahoo.com.br; 2. Universidade Federal Rural do Rio de Janeiro, Instituto de Zootecnia, \\ Departamento Nutrição Animal e Pastagens, Seropédica, RJ, Brazil; 3. Empresa Brasileira de Pesquisa Agropecuária, Centro Nacional \\ de Pesquisa de Gado de Leite, Juiz de Fora, MG, Brazil; 4. Universidade Federal do Vale do São Francisco, Colegiado de Zootecnia, \\ Petrolina, PE, Brazil.
}

\begin{abstract}
The objective of this work was to evaluate the use of citrus pulp addition and wilting on fermentative characteristics, chemical composition as well as gas and effluent losses of elephant grass silage. The elephant grass (70 growth days) was collected manually; one portion was immediately chopped and another one was allowed to wilt in the sun for a period of $6 \mathrm{~h}$ and subsequently chopped for the production of silage. Experimental PVC silos $(10 \mathrm{~cm}$ diameter x $30 \mathrm{~cm}$ height) were used and sand bags were placed at the bottom of the silos. Citrus pulp $\left(80 \mathrm{~g} \mathrm{~kg}^{-1} \mathrm{of} \mathrm{MN}\right)$ was added at the beginning of ensilage. The ensiled material was manually compressed to provide a specific mass of approximately $600 \mathrm{~kg} \mathrm{~m}^{-3}$ of silage. After 60 days, the silos were opened; gas and effluent losses were calculated and we determined $\mathrm{pH}$, dry matter (DM), crude protein(CP), neutral detergent fibre (NDF), lignin, ammonia nitrogen, ash and in vitro dry matter digestibility (IVDMD). We added 0 or $80 \mathrm{~g} \mathrm{~kg}^{-1}$ of citrus pulp to wilted and un-wilted elephant grass. We used a completely randomised design with a $2 \times 2$ factorial arrangement (wilted or un-wilted) $\mathrm{x}$ (with or without citrus pulp), totalling treatments with five repetitions. Average values were compared using the $\mathrm{F}$ test with a probability of 5\%. The addition of citrus pulp resulted in reduced levels of NDF, lignin, ash, $\mathrm{N}-\mathrm{NH}_{3}$ and $\mathrm{pH}$ and in increased values of DM and IVDMD of silages. Wilting increased the DM, NDF and lignin values and reduced the concentrations of CP, IVDMD and $\mathrm{N}_{-} \mathrm{NH}_{3}$. Based on our results, citrus pulp addition improves the chemical composition of elephant grass silage and increases its in vitro dry matter digestibility.
\end{abstract}

KEYSWORDS: Additive. Moisture. Pennisetum purpureum.

\section{INTRODUCTION}

Among the factors affecting cattle productivity in Brazil, forage production seasonality has been highlighted. Grasses potentially produce high amounts of dry matter. However, biomass production is highly influenced by climatic factors, and extremely dry periods may result in substantial losses (BOTREL et al., 2002; ALENCAR et al., 2009).

In this context, pasture-based animal production is highly dependent on forage production, and particularly in the rainy season, the application of forage surplus conservation methods is required (GONÇALVES et al., 2008). Among forage conservation methods, silage making is widely used by producers due to its simple application. However, dry matter contents and concentrations of soluble carbohydrates at silage time significantly impact silage quality (SANTOS et al., 2010). As tropical grasses are perennial with a high dry matter production during the rainy season, silage lends itself as a method to minimize forage shortages during the dry season using the production surplus (ALENCAR et al., 2009; FERREIRA et al., 2015).

Among the grasses used for silage production, elephant grass has a particularly high dry matter production and nutritional value. However, despite the high nutritional value, the dry matter content, soluble carbohydrate level and buffer capacity of this species are not suitable for an efficient fermentation process (BERGAMASCHINE et al., 2006; FERREIRA et al., 2015). Citrus pulp is extremely absorbent, increasing its weight by up to $145 \%$ when in contact with moist forage, thereby preserving nutrients that would be lost by secondary fermentation or in the form of effluents (RIBEIRO et al., 2009).

In this sense, the use of techniques to reduce moisture, in addition to other techniques improving nutritional values of silage, might be important in establishing a grass silage fermentation pattern and, 
consequently, in the production of high-quality livestock feed.

This study evaluated the use of citric pulp in silage making and the effects of forage wilting on fermentation traits, chemical composition and losses of elephant grass silage.

\section{MATERIAL AND METHODS}

Elephant grass (Pennisetum purpureum Schumach.) used in silage production was harvested in the elephant grass cv. Taiwan A-146 area, Universidade Federal Rural do Rio de Janeiro $\left(22^{\circ} 46^{\prime} 25^{\prime \prime} \mathrm{S}, 4^{\circ} 41^{\prime} 15^{\prime \prime}, \mathrm{W}\right.$ and $36 \mathrm{~m}$ of elevation), Seropédica, State of Rio de Janeiro, Brazil. Climate has been characterized as Aw type according to the Köppen classification (KOTTEK et al., 2006). The area has a mean annual rainfall of $1,285 \mathrm{~mm}$; the rainy season (October to March) is warm, while the dry season, representing winter (April to September), is mild.

Immediately after silage production, the silos were transported to Embrapa Gado de Leite, Juiz de Fora, Minas Gerais state, Brazil, for laboratory tests.

After a uniform cut of the experimental area, base fertilisation with $100 \mathrm{~kg} \mathrm{ha}^{-1} \mathrm{~N}$ and $\mathrm{K}_{2} \mathrm{O}$ was performed. Elephant grass was harvested when it reached a height of $1.8 \mathrm{~m}$ high at 70-days regrowth at $20 \mathrm{~cm}$ above the soil. One part of the grass was immediately chopped and ensiled, while the other part was left to wilt in the sun under a canvas for six hours and subsequently chopped and ensiled.

We used experimental PVC silos $(10 \mathrm{~cm}$ diameter $\times 30 \mathrm{~cm}$ height) with Bunsen valves at the cover. For effluent collection at the bottom of the silos, sealed sewing TNT bags containing $0.5 \mathrm{~kg}$ dry sand at were placed into the silos at $65^{\circ} \mathrm{C}$ for $72 \mathrm{~h}$.

Citrus pulp was homogeneously mixed with $80 \mathrm{~g} \mathrm{~kg}^{-1}$ elephant grass at ensiling (RODRIGUES et al. 2005); the ensiled material was manually compressed, providing $600 \mathrm{~kg} \mathrm{~m}^{-3}$ density. Silos were weighed empty and filled after ensiling. After 60 days, the silos were again weighted to determine weight loss and subsequently opened. After opening, the sand bags were also weighed to determine effluent losses.

Elephant grass and citrus pulp samples were taken prior to ensiling and silage samples at the time of opening the silos.

In accordance to Playne and McDonald (1966), for buffer determination, another grass portion was frozen, 15 to $20 \mathrm{~g}$ fresh material were weighed, following maceration in a blender with
$250 \mathrm{ml}$ distilled water. Macerate was firstly titrated at $3.0 \mathrm{pH}$ with $0.1 \mathrm{~N} \mathrm{HCl}$ to liberate bicarbonates and $\mathrm{CO}_{2}$ and then titrated at $6.0 \mathrm{pH}$ with $0.1 \mathrm{~N}$ $\mathrm{NaOH}$. Buffer was expressed as alkali milligram equivalent required for changing the $\mathrm{pH}$ from 4.0 to 6.0 by $100 \mathrm{~g}$ dry matter, after titration correction for $250 \mathrm{ml}$ water.

One part of the silage sample was weighed, dried in a forced ventilation oven at $55^{\circ} \mathrm{C}$ and ground at $1.0 \mathrm{~mm}$ in a Willy mill for chemical composition analyses. The other part was used to extract juice by a hydraulic press to determine $\mathrm{pH}$, ammonia-nitrogen, and volatile fatty acids.

We performed the following chemical analyses: dry matter(DM, method number 967.03; AOAC, 1990), crude protein (CP, method number 984.13; AOAC, 1990), neutral detergent fibre (NDF, VAN SOEST et al., 1991), lignin (sulfuric acid $72 \% \mathrm{w} / \mathrm{w}$ ), ash (method number 942.05; AOAC, 1990) and in vitro dry matter digestibility (IVDMD) according to Tilley and Terry (1963), using the two-stage technique.

Dry matter losses by gases and effluents were quantified by weight difference. Gas losses were calculated using equation one (JOBIM et al., 2007):

$\mathrm{GL}=(\mathrm{ESW}-\mathrm{OSW}) /(\mathrm{EF} \times \mathrm{FEDM}) \times 1000 ; \quad$ Eq. (1) where: $\mathrm{GL}=$ gases loss at storage $\left(\mathrm{g} \mathrm{kg}^{-1}\right.$ of initial $\mathrm{DM}) ; \mathrm{ESW}=$ ensiling silo weight; OSW = opening silo weight; $\mathrm{EF}=$ ensiling forage mass and FEDM = forage ensiling dry matter.

Effluent losses were calculated using the following equation (JOBIM et al., 2007):

$\mathrm{EP}=[(\mathrm{OSW}-\mathrm{ESW}) /(\mathrm{EFGM})] \times 1000$;

where: $\mathrm{EP}=$ effluent production $\left(\mathrm{g} \mathrm{kg}^{-1}\right.$ as fed); OSW $=$ opening set weight $=($ silo + sand $) ; \mathrm{ESW}=$ ensiling set weight $=($ silo + sand $) ; E F G M=$ ensiled forage mass.

We used a completely randomised design with a $2 \times 2$ factorial arrangement (wilted or unwilted) $\mathrm{x}$ (with or without citrus pulp), totalizing 4 treatments with 5 replicates with 20 parcels. The measured variables were analysed according to the following statistical model:

$y_{i j k}=\mu+\alpha_{i}+\beta_{j}+\alpha \beta_{i j}+e_{i j k}$

where $y$ is the measured variable taken in the wilted $(j=2)$ or un-wilted $(j=1)$ silage contained in the $k$-th mini-silo with $(\mathrm{i}=1)$ or without $(\mathrm{i}=2)$ citrus pulp addition and $\alpha \beta_{v j}$ represents the interaction of citrus pulp and wilting. The model was fitted by using the MIXED procedure of SAS according to the recommendations described by Littell et al. (2006). The estimation procedure REML was used as the default and the heterogeneity of the variables 
was checked by the grouping command in the repeated sentence of the MIXED procedure. The grouping factors were $\alpha, \beta$, and the interaction $u \beta$. The random error term was assumed normal, independent and identically distributed. The best variance structure was chosen based on the Akaike Information Criterion (AKAIKE, 1974) corrected for small samples (SUGIURA, 1978), termed as AICc. The computed AICc values were compared by its derived measures according to Burnham and Anderson (2004) and Vieira et al. (2012). Confidence intervals were generated by considering a confidence level of $99 \%$ according to the recommendations presented by Cohen (2011). Confidence intervals were presented as follows:

$$
99 \% \text { Cl: } \bar{y} \pm(\text { upper -lower }) / 2 ; \quad \text { Eq. (4) }
$$

where the quantity (upper lower) is the amplitude of the $99 \% \mathrm{Cl}$ and $y$ is the least squares mean of the variable.

\section{RESULTS AND DISCUSSION}

Table 1 shows the chemical composition of treatments and citrus pulp. The variables lactic:acetic acid ratio, propionic acid, acetic acid, lignin, ash, neutral detergent insoluble nitrogen, ADF and crude protein fitted best to the model of homogeneous variance. The parameters $\mathrm{NH}_{3}-\mathrm{N}$, NDF, IVDMD and DM fitted best to the heterogeneous variance for citrus pulp and wilting in regards to lactic acid fitted best to the heterogeneous variance for wilting. In terms of wilting $\mathrm{x}$ citrus pulp interaction, the most suitable model was also the heterogeneous variance structure for the variables $\mathrm{pH}$, gases and effluents losses.

There was a significant interaction between citrus pulp and wilting on effluent loss (Table 2). As citrus pulp as wilting employment were effective regarding on reduced effluent loss, with no treatment elephant grass silage presenting the highest effluent loss and silage with two associated treatments presenting the lowest effluents loss, as well. Effluent production decreased as silage dry matter content increased. Wilting, citrus pulp use and both treatments combined reduced effluent production by $46.71,63.28$ and $90.2 \%$, respectively. Loures et al. (2005) have reported significant effluent losses at a dry matter content below $300 \mathrm{~g}$ $\mathrm{kg}^{-1}$. Similarly, Rezende et al. (2008) have observed an effluent loss of $24.89 \mathrm{~g} \mathrm{~kg}^{-1}$ in elephant grass silages with a dry matter content of $237.6 \mathrm{~g} \mathrm{~kg}^{-1}$. Gas losses were reduced by wilting and citrus pulp employment, although the interactive effect of the two treatments was not significant (Table 2). Our data indicate that wilting and citrus pulp employment enhanced the fermentative process by reducing the moisture content of the ensiles material; the treatments using citrus pulp, contents of soluble carbohydrates were higher. The gas losses in our study were higher than those reported by Rezende et al. (2008) for elephant grass silage without citrus pulp (10.8 $\left.\mathrm{g} \mathrm{kg}^{-1} \mathrm{DM}\right)$ and with $70 \mathrm{~g}$ citrus pulp kg-1 DM (25.5 $\left.\mathrm{g} \mathrm{kg}^{-1} \mathrm{DM}\right)$. However, the authors have reported silages with higher dry matter contents (237.6 $\mathrm{g} \mathrm{kg}^{-1}$ as fed with no citrus pulp and $269.2 \mathrm{~g} \mathrm{~kg}^{-1}$ as fed with citrus pulp). This fact can be explained by the high moisture absorption capacity of citrus pulp, leading to an improved fermentation profile (RIBEIRO et al., 2009).

Elephant-grass silages dry matter content was increased as by wilting as by citrus pulp (Table 3 ). With the use of citrus pulp, DM contents increased by $41.03 \%$ compared to the control, while wilting increased DM by $12.41 \%$ compared to the control. This suggests that the wilting period of six hours was insufficient. Although we observed DM increases in both treatments, Haigh (1999) has reported DM contents lower than $250 \mathrm{~g} \mathrm{~kg}^{-1}$ as feed for minimum effluent production and below $300 \mathrm{~g}$ $\mathrm{kg}^{-1}$ as feed for optimal fermentation (MCDONALD et al., 1991). The interaction effect of wilting and citrus pulp of crude protein contents was significant (Table 3). The lowest CP content was observed in silage with combined citrus pulp and wilting. According to Guim et al. (2002), this could be explained by the conversion of nitrate on ensiled grass into microbial protein. The values in our study were higher than those reported by Rezende et al. (2008) studying elephant grass silages with citrus pulp (70 $\left.\mathrm{g} \mathrm{kg}^{-1} \mathrm{DM}\right)$ and without citrus pulp. Our values of CP were higher than $70 \mathrm{~g} \mathrm{~kg}^{-1} \mathrm{DM}$, the minimum value for optimum rumen function (SILVA; LEÃO, 1979).

The interaction effect between wilting and citrus pulp on NDF was not significant (Table 3). Addition of citrus pulp decreased elephant grass silage NDF, which might be explained by the low NDF content of this additive $\left(259.7 \mathrm{~g} \mathrm{~kg}^{-1} \mathrm{DM}\right)$ in comparison to that of elephant grass $\left(729.7 \mathrm{~g} \mathrm{~kg}^{-1}\right.$ DM). 
Table 1. Chemical composition of elephant grass, wilted or un-wilted, citrus pulp and associations.

\begin{tabular}{|c|c|c|c|c|c|}
\hline Variable & $\mathrm{C}^{2}$ & $\mathrm{EG}^{2}$ & $\mathrm{EGW}^{2}$ & $\overline{E G+C^{2}}$ & $\overline{E G W+C^{2}}$ \\
\hline $\mathrm{DM}^{1}\left(\mathrm{~g} \mathrm{~kg}^{-1}\right.$ as fed $)$ & 849.3 & 133.4 & 167.7 & 172.6 & 219.6 \\
\hline $\mathrm{CP}^{1}\left(\mathrm{~g} \mathrm{~kg}^{-1} \mathrm{DM}\right)$ & 70.6 & 113.0 & 104.7 & 115.5 & 108.1 \\
\hline $\mathrm{NDF}^{1}\left(\mathrm{~g} \mathrm{~kg}^{-1} \mathrm{DM}\right)$ & 259.7 & 729.7 & 684.1 & 701.8 & 672.6 \\
\hline $\operatorname{Lignin}\left(\mathrm{g} \mathrm{kg}^{-1} \mathrm{DM}\right)$ & 71.4 & 62.1 & 67.8 & 76.4 & 66.4 \\
\hline Ash $\left(\mathrm{g} \mathrm{kg}^{-1} \mathrm{DM}\right)$ & 17.6 & 22.8 & 21.5 & 22.1 & 21.7 \\
\hline $\mathrm{SC}^{1}\left(\mathrm{~g} \mathrm{~kg}^{-1} \mathrm{DM}\right)$ & 276.7 & 195.6 & 192.2 & 206.4 & 201.5 \\
\hline $\mathrm{BP}^{1}\left(\mathrm{mEqHCl} 100 \mathrm{~g}^{-1} \mathrm{DM}\right)$ & - & 22.95 & 23.01 & 23.94 & 21.85 \\
\hline
\end{tabular}

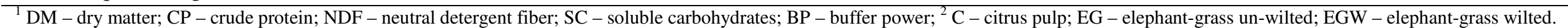

Table 2. Effluents and gas losses of elephant grass silages produced with citrus pulp addition and wilting.

\begin{tabular}{|c|c|c|c|c|c|c|c|}
\hline \multirow[t]{2}{*}{ Variable } & \multirow{2}{*}{ Citrus Pulp } & \multicolumn{2}{|c|}{ Wilted } & \multirow{2}{*}{ Mean } & \multicolumn{3}{|c|}{$\mathrm{P}$ - value } \\
\hline & & Without & With & & $\mathrm{W}^{1}$ & $\mathrm{C}^{1}$ & $\mathrm{~W} \times \mathrm{C}^{1}$ \\
\hline \multirow[t]{4}{*}{ Gases losses $\left(\mathrm{g} \mathrm{kg}^{-1}\right.$ as fed $)$} & & & & & 0.1047 & 0.0836 & 0.4391 \\
\hline & Without & $129.15 \pm 205.09 \mathrm{Aa}$ & $63.26 \pm 29.72 \mathrm{Ba}$ & $96.21 \pm 100.82$ & & & \\
\hline & With & $58.92 \pm 30.15 \mathrm{Ab}$ & $31.77 \pm 10.45 \mathrm{Aa}$ & $45.35 \pm 14.05$ & & & \\
\hline & Mean & $94.04 \pm 100.77$ & $47.52 \pm 13.83$ & & & & \\
\hline \multirow[t]{4}{*}{ Effluents Losses $\left(\mathrm{g} \mathrm{kg}^{-1} \mathrm{DM}^{1}\right)$} & & & & & 0.0002 & $<0.0001$ & 0.0417 \\
\hline & Without & $105.87 \pm 10.37 \mathrm{Bb}$ & $56.99 \pm 38.82 \mathrm{Ba}$ & $81.43 \pm 18.48$ & & & \\
\hline & With & $34.88 \pm 16.83 \mathrm{Ab}$ & 10.37+9.74Aa & $22.63 \pm 7.63$ & & & \\
\hline & Mean & $70.38 \pm 7.65$ & $33.68 \pm 18.57$ & & & & \\
\hline
\end{tabular}

Means followed by the same letter, small letters on the same line and capital letters on the same column do not differ by $\mathrm{F}$ test $(\mathrm{P}<0.05)$.

${ }^{1} \mathrm{DM}$ - dry matter; $\mathrm{W}$ - wilted; C - citrus pulp. 
Table 3. Chemical composition of elephant grass silages produced with citrus pulp addition and wilting.

\begin{tabular}{|c|c|c|c|c|c|c|c|}
\hline \multirow{2}{*}{ Variable } & \multirow{2}{*}{ Citrus Pulp } & \multicolumn{2}{|c|}{ Wilted } & \multirow{2}{*}{ Mean } & \multicolumn{3}{|c|}{$P$ - value } \\
\hline & & Without & With & & $\mathrm{W}^{1}$ & $\mathrm{C}^{1}$ & $\mathrm{~W} \times \mathrm{C}^{1}$ \\
\hline \multirow[t]{4}{*}{$\mathrm{DM}^{1}\left(\mathrm{~g} \mathrm{~kg}^{-1}\right.$ as fed $)$} & & & & & $<0.0001$ & $<0.0001$ & 0.8879 \\
\hline & Without & $142.18 \pm 7.70 \mathrm{Aa}$ & $163.19 \pm 7.70 \mathrm{Ab}$ & $152.69 \pm 5.44$ & & & \\
\hline & With & $202.35 \pm 13.95 \mathrm{Ba}$ & $226.33 \pm 13.94 \mathrm{Bb}$ & $215.34 \pm 9.86$ & & & \\
\hline & Mean & $173.26 \pm 7.20$ & $194.76 \pm 7.20$ & & & & \\
\hline \multirow[t]{4}{*}{$\mathrm{CP}^{1}\left(\mathrm{~g} \mathrm{~kg}^{-1} \mathrm{DM}\right)$} & & & & & 0.0056 & 0.2129 & 0.0470 \\
\hline & Without & $95.28 \pm 7.92 \mathrm{Aa}$ & $92.44 \pm 7.92 \mathrm{Ba}$ & $93.86 \pm 5.60$ & & & \\
\hline & With & $97.60 \pm 7.92 \mathrm{Ab}$ & $83.08 \pm 7.92 \mathrm{Aa}$ & $90.34 \pm 5.60$ & & & \\
\hline & Mean & $96.44 \pm 5.60$ & $87.76 \pm 5.60$ & & & & \\
\hline \multirow[t]{4}{*}{$\mathrm{NDF}^{1}\left(\mathrm{~g} \mathrm{~kg}^{-1} \mathrm{DM}\right)$} & & & & & 0.0326 & $<0.0001$ & 0,0527 \\
\hline & Without & $701.00 \pm 12.29 \mathrm{Ba}$ & $702.98 \pm 12.29 \mathrm{Ba}$ & $701.99 \pm 8.69$ & & & \\
\hline & With & $552.54 \pm 31.54 \mathrm{Aa}$ & $585.72 \pm 31.54 \mathrm{Ab}$ & $569.13 \pm 22.30$ & & & \\
\hline & Mean & $626.77 \pm 15.86$ & $644.35 \pm 15.86$ & & & & \\
\hline \multirow[t]{4}{*}{$\operatorname{Lignin}\left(\mathrm{g} \mathrm{kg}^{-1} \mathrm{DM}\right)$} & & & & & $<0.0001$ & 0.0047 & 0.5898 \\
\hline & Without & $46.24 \pm 3.72 \mathrm{Ba}$ & $55.36 \pm 3.72 \mathrm{Ab}$ & $50.80 \pm 2.63$ & & & \\
\hline & With & $41.36 \pm 3.72 \mathrm{Aa}$ & $51.88 \pm 3.72 \mathrm{Ab}$ & $46.62 \pm 2.63$ & & & \\
\hline & Mean & $43.80 \pm 2.63$ & $53.63 \pm 2.63$ & & & & \\
\hline \multirow[t]{4}{*}{ Ash $\left(\mathrm{g} \mathrm{kg}^{-1} \mathrm{DM}\right)$} & & & & & 0.0840 & 0.0231 & 0.3299 \\
\hline & Without & $28.46 \pm 4.88 \mathrm{Ba}$ & $23.70 \pm 4.88 \mathrm{Aa}$ & $26.08 \pm 3.45$ & & & \\
\hline & With & $22.58 \pm 4.88 \mathrm{Aa}$ & $21.18 \pm 4.88 \mathrm{Aa}$ & $21.88 \pm 3.45$ & & & \\
\hline & Mean & $25.52 \pm 3.45$ & $22.44 \pm 3.45$ & & & & \\
\hline \multirow[t]{4}{*}{$\operatorname{IVDMD}^{1}\left(\mathrm{~g} \mathrm{~kg}^{-1} \mathrm{DM}\right)$} & & & & & 0.047 & $<0.0001$ & 0.7978 \\
\hline & Without & $487.78 \pm 19.59 \mathrm{Ab}$ & $438.91 \pm 1.59 \mathrm{Aa}$ & $473.14 \pm 13.85$ & & & \\
\hline & With & $619.40 \pm 38.59 \mathrm{Ba}$ & $585.34 \pm 38.59 \mathrm{Ba}$ & $602.37 \pm 27.29$ & & & \\
\hline & Mean & $553.59 \pm 19.74$ & $521.92 \pm 19.74$ & & & & \\
\hline
\end{tabular}


Our results are in agreement with those reported by Ferrari Júnior et al. (2009), who evaluated the effects of several additives to elephant grass ensilage. The silage NDF content was increased by wilting, which is in contrast to the results reported by Carvalho et al. (2007), who found lower NDF contents of wilted elephant grass silages. However, higher NDF contents were somehow expected for the wilted forages as a result of decreased amounts of soluble compounds due to sun exposure (EVANGELISTA et al., 2000). Citrus pulp silages presented NDF contents below the critical threshold of $600 \mathrm{~g} \mathrm{~kg}^{-1} \mathrm{DM}$, the NDF limit not affecting intake by ruminants (VAN SOEST, 1994).

Lignin contents were affected by wilting and citrus pulp employment (Table 3). Elephant grass silages produced with citrus pulp presented lower lignin contents due to the dilution effect caused by the citrus pulp. Wilting increased lignin contents. However, Carvalho et al. (2007) could not observed any differences in lignin contents between wilted or un-wilted elephant grass silages. According to Van Soest (1994), lignin is the limiting factor to plant cell wall availability to herbivore animals on anaerobic digestion as well as; it can therefore be considered as an anti-nutritional factor (FARIA et al., 2007). The values observed in our study were lower than those reported by Rodrigues et al. (2005) studying elephant grass silages with citrus pulp addition. Ash contents were reduced by citrus pulp addition, this result is in contrast to the findings reported by Ferrari Júnior et al. (2009), who observed increased ash contents with the addition of $50 \mathrm{~g} \mathrm{~kg}^{-1}$ of citrus pulp (Table 3 ). However, values reported were lower than those ones showed on literature (PEREIRA et al., 1999; CARVALHO et al., 2007). Wilting had no effect on ash contents, which is in agreement with the findings of Carvalho et al. (2007).

The interaction effect between citrus pulp addition and wilting on IVDMD was not significant (Table 3). Wilted elephant grass silages presented lower IVDMD values compared to un-wilted ones, which was most likely due to the higher fibrous fraction of wilted silages. Carvalho et al. (2007) observed no differences in IVDMD values of elephant grass silages wilted for 8 hours un-wilted. Citrus pulp addition increased elephant grass silage IVDMD, and this higher IVDMD value might be related to the lower fibre levels (REZENDE et al., 2008), in addition to the promotion of more favourable fermentation conditions by decreasing proteolysis through $\mathrm{pH}$ reduction (TAVARES et al., 2009). Ferrari Júnior et al. (2009) have reported higher IVDMD values when citrus pulp was added. The addition of citrus pulp had a notable effect on $\mathrm{pH}$ values, reducing the $\mathrm{pH}$ from (Table 4) 4.5 to 3.5 , indicating an enhanced fermentation process due to higher fermentable substrate concentrations. Ferrari Júnior et al. (2009) have observed decreases in $\mathrm{pH}$ values with citrus pulp inclusion of $50 \mathrm{~g} \mathrm{~kg}^{-1}$ DM; however, Rodrigues et al. (2005) did not observe any effects of citrus pulp on $\mathrm{pH}$ values. The $\mathrm{pH}$ values of wilted silages were below the recommended threshold of 4.2 (MCDONALD et al., 1991).

The interaction effect between citrus pulp and wilting on $\mathrm{NH}_{3}-\mathrm{N}$ contents was significant (Table 4). In silages with no citrus pulp, wilting decreased $\mathrm{NH}_{3}-\mathrm{N}$ contents, while in silages with no wilting, citrus pulp decreased $\mathrm{NH}_{3}-\mathrm{N}$ contents. Elephant grass silages produced with citrus pulp presented $\mathrm{NH}_{3}-\mathrm{N}$ levels below $100 \mathrm{~g} \mathrm{~kg}^{-1}$ of $\mathrm{N}$, indicating that the fermentation process does not result in excessive protein breakdown into ammonia (VAN SOEST, 1994). However, $\mathrm{NH}_{3}-\mathrm{N}$ contents above $150 \mathrm{~g} \mathrm{~kg}^{-1} \mathrm{~N}$ in the control silage indicate intensive proteolysis. Therefore, the use of these silages might result in low acceptability and, consequently, low animal intake (FARIA et al., 2007). The $\mathrm{NH}_{3}-\mathrm{N}$ values of wilted elephant grass silages were similar to those reported by Tosi et al. (1999), who reported $165 \mathrm{~g} \mathrm{~kg}^{-1} \mathrm{~N}$ in wilted elephant-grass silage.

We found no butyric acid in the silages, indicating that despite the high moisture and ammonia nitrogen contents, Clostridium bacteria were not present. The addition of citrus pulp affected lactic acid contents, indicating that citrus pulp provided additional soluble carbohydrates for the fermentation process (Table 4). Acetic acid contents were not affected by any of the treatments (Table 4). Citrus pulp addition was responsible for propionic acid content alterations (Table 4). In our study, organic acid contents were higher than those reported by Ferrari Júnior and Lavezzo (2001), who studied the use of wilted and un-wilted elephant grass for silage production. However, it should be mentioned that there was a short-term $\mathrm{pH}$ decrease, impeding secondary fermentation due to the high lactic acid contents and low acetic, propionic and butyric acid contents. 
Table 4. Fermentative characteristics of elephant grass silages produced with citrus pulp addition and wilting.

\begin{tabular}{|c|c|c|c|c|c|c|c|}
\hline \multirow[t]{2}{*}{ Variable } & \multirow{2}{*}{ Citrus Pulp } & \multicolumn{2}{|c|}{ Wilted } & \multirow{2}{*}{ Mean } & \multicolumn{3}{|c|}{$\mathrm{P}$ - value } \\
\hline & & Without & With & & $\mathrm{W}^{1}$ & $\mathrm{C}^{1}$ & $\mathrm{~W} \times \mathrm{C}^{1}$ \\
\hline \multirow{4}{*}{$\mathrm{pH}$} & & & & & 0.125 & 0.0122 & 0.166 \\
\hline & Without & $4.86 \pm 1.77 \mathrm{Ba}$ & $4.14 \pm 0.79 \mathrm{Ba}$ & $4.50 \pm 0.81$ & & & \\
\hline & With & $3.77 \pm 0.48 \mathrm{Aa}$ & $3.72 \pm 0.13 \mathrm{Aa}$ & $3.75 \pm 0.23$ & & & \\
\hline & Mean & $4.32 \pm 0.84$ & $3.93 \pm 0.38$ & & & & \\
\hline \multirow[t]{4}{*}{$\mathrm{NH}_{3}-\mathrm{N}^{1}\left(\mathrm{~g} \mathrm{~kg}^{-1} \mathrm{~N}\right)$} & & & & & 0.0034 & 0.0004 & 0.0083 \\
\hline & Without & $352.48 \pm 132.85 \mathrm{Bb}$ & $140.38 \pm 132.85 \mathrm{Aa}$ & $246.43 \pm 93.24$ & & & \\
\hline & With & $96.15 \pm 15.97 \mathrm{Ab}$ & $78.56 \pm 15.97 \mathrm{Aa}$ & $87.36 \pm 11.29$ & & & \\
\hline & Mean & $224.32 \pm 6.36$ & $109.47 \pm 66.36$ & & & & \\
\hline \multirow[t]{4}{*}{ Lactic acid $\left(\mathrm{g} \mathrm{kg}^{-1} \mathrm{DM}\right)$} & & & & & 0.5471 & 0.0022 & 0.1147 \\
\hline & Without & $116.84 \pm 122.38 \mathrm{Aa}$ & $181.60 \pm 46.75 \mathrm{Aa}$ & $149.22 \pm 61.48$ & & & \\
\hline & With & $276.36 \pm 122.38 \mathrm{Ba}$ & $245.98 \pm 46.75 \mathrm{Ba}$ & $261.17 \pm 61.48$ & & & \\
\hline & Mean & $196.60 \pm 86.54$ & $213.79 \pm 33.06$ & & & & \\
\hline \multirow[t]{4}{*}{ Acetic acid $\left(\mathrm{g} \mathrm{kg}^{-1} \mathrm{DM}\right)$} & & & & & 0.7242 & 0.0835 & 0.3183 \\
\hline & Without & $64.44 \pm 16.34 \mathrm{Aa}$ & $72.21 \pm 16.34 \mathrm{Aa}$ & $68.32 \pm 11.56$ & & & \\
\hline & With & $59.87 \pm 16.34 \mathrm{Aa}$ & $56.12 \pm 16.34 \mathrm{Aa}$ & $57.99 \pm 11.56$ & & & \\
\hline & Mean & $62.15 \pm 11.56$ & $64.16 \pm 11.56$ & & & & \\
\hline \multirow[t]{4}{*}{ Propionic acid $\left(\mathrm{g} \mathrm{kg}^{-1} \mathrm{DM}\right)$} & & & & & 0.3532 & 0.0001 & 0.0568 \\
\hline & Without & $1.32 \pm 0.71 \mathrm{Aa}$ & $2.05 \pm 0.71 \mathrm{Ab}$ & $1.69 \pm 0.50 \mathrm{~A}$ & & & \\
\hline & With & $3.05 \pm 0.71 \mathrm{Ba}$ & $2.79 \pm 0.71 \mathrm{Ba}$ & $2.92 \pm 0.50 \mathrm{~B}$ & & & \\
\hline & Mean & $2.19 \pm 0.50 \mathrm{a}$ & $2.42 \pm 0.50 \mathrm{a}$ & & & & \\
\hline
\end{tabular}




\section{CONCLUSION}

The use of $80 \mathrm{~g}$ citrus pulp $\mathrm{kg}^{-1}$ markedly improves the quality of elephant grass silage.

RESUMO: Objetivou-se avaliar o uso de polpa cítrica e do emurchecimento sobre as características fermentativas, composição química e perdas de silagens de capim-elefante. O capim-elefante foi colhido manualmente com cerca de 70 dias de rebrota, uma parte foi picada imediatamente e outra foi emurchecida ao sol por 6 horas e posteriormente picado para confecção das silagens. Foram utilizados silos experimentais de PVC com $10 \mathrm{~cm}$ de diâmetro e $30 \mathrm{~cm}$ de altura, no fundo dos silos foram colocados sacos com areia. A polpa cítrica foi incluída na base de $80 \mathrm{~g} \mathrm{~kg}^{-1} \mathrm{da}$ matéria natural no momento da ensilagem. O material ensilado foi compactado manualmente de forma a proporcionar massa específica de aproximadamente $600 \mathrm{~kg} \mathrm{~m}^{-3}$ de silagem. No momento da ensilagem foram pesados os silos vazios, os sacos com areia, o material ensilado e os silos cheios. Após 60 dias os silos foram pesados novamente e logo em seguida abertos. Foram calculadas as perdas por gases e efluentes e determinados o pH, conteúdo de matéria seca, teores de proteína bruta, fibra em detergente neutro (FDN), fibra em detergente ácido (FDA), celulose, hemicelulose e lignina, cinzas, nitrogênio amoniacal e digestibilidade in vitro da matéria seca (DIVMS). Foi utilizado o delineamento inteiramente casualisado em arranjo fatorial 2 (emurchecido ou não) x 2 (com polpa cítrica ou não), 4 tratamentos com 5 repetições, totalizando 20 parcelas. As médias foram comparadas pelo teste $\mathrm{F}$ a 5\%. O uso de polpa cítrica reduziu os níveis de FDN, lignina, cinzas, $\mathrm{N}-\mathrm{NH}_{3}$ e o $\mathrm{pH}$ e aumentou a MS e a DIVMS das silagens. O emurchecimento aumentou a MS, FDN e a lignina e reduziu a proteína bruta, DIVMS e $\mathrm{N}-\mathrm{NH}_{3}$. O uso da polpa cítrica melhora a composição química e a digestibilidade in vitro da matéria seca de silagens de capim-elefante.

PALAVRAS-CHAVE: Aditivo. Pennisetum purpureum. Umidade.

\section{REFERENCES}

AKAIKE, H. A new look at the statistical model identification. IEEE Transactions on Automatic Control, Notre Dame, v. 19, p. 716-723, 1974. https://doi.org/10.1109/TAC.1974.1100705

ALENCAR, C. A. B.; CÓSER, A. C.; OLIVEIRA, R. A.; MARTINS, C. E.; CUNHA, F. F.; FIGUEIREDO, J. L. A. Produção de seis gramíneas manejadas por corte sob efeito de diferentes lâminas de irrigação e estações anuais. Ciência e Agrotecnologia, Lavras, v. 33, p. 1307-1313, 2009.

AOAC - ASSOCIATION OF OFFICIAL ANALYTICAL CHEMISTRY. Official methods of analysis. 15th ed. Washington: AOAC International, 1990. 1298 p.

BERGAMASCHINE, A. F.; PASSIPIÉRI, M.; VERIANO FILHO, W. V.; ISEPON, O. J.; CORREA, L. A. Qualidade e valor nutritivo de silagens de capim-marandu (B. brizantha cv. Marandu) produzidas com aditivos ou forragem emurchecida. Revista Brasileira de Zootecnia, Viçosa, v. 35, p. 1454-1462, 2006.

BOTREL, M. A.; ALVIM, M. J.; FERREIRA, R. P.; XAVIER, D. F. P. Potencial forrageiro de gramíneas em condições de baixas temperaturas e altitude elevada. Pesquisa Agropecuária Brasileira, Brasília, v. 37, p. 393-398, 2002. https://doi.org/10.1590/S0100-204X2002000300021

BURNHAM, K. P.; ANDERSON, D. R. Multimodel Inference: Understanding AIC and BIC in Model Selection. Sociological Methods \& Research, Thousand Oaks, v. 33, p. 261-304, 2004.

https://doi.org/10.1177/0049124104268644

CARVAlHO, G. G. P.; GARCIA, R.; PIRES, A. J. V. PEREIRA, O. G.; AZEVÊDO, J. A. G.; CARVALHO, B. M. A.; CAVALI, J. Valor nutritivo de silagens de capim-elefante emurchecido ou com adição de farelo de cacau. Revista Brasileira de Zootecnia, Viçosa, v. 36, p. 1495-1501, 2007.

COHEN, H. W. P-values: use and misuse in medical literature. American Journal of Hypertension, Oxford, v. 24, p. 18-23, 2011. https://doi.org/10.1038/ajh.2010.205 
EVANGELISTA, A. R.; LIMA, J. A.; BERNARDES, T. F. Avaliação de algumas características da silagem de gramínea estrela roxa (Cynodon nlemfuensis Vanderyst). Revista Brasileira de Zootecnia, Viçosa, v. 29, p. 941-946, 2000.

FARIA, D. J. G.; GARCIA, R.; PEREIRA, O. G.; FONSECA, D. M.; MELLO, R.; RIGUEIRA, J. P. S. Composição químico-bromatológica da silagem de capim-elefante com níveis de casca de café. Revista Brasileira de Zootecnia, Viçosa, v. 36, p. 301-308, 2007.

FERRARI JÚNIOR, E.; LAVEZZO, W. Qualidade da silagem de capim-elefante (Pennisetum purpureum Schum.) emurchecido ou acrescido de farelo de mandioca. Revista Brasileira de Zootecnia, Viçosa, v. 30, p. 1424-1431, 2001. https://doi.org/10.4321/s0004-05922009000200003

FERRARI JÚNIOR, E.; PAULINO, V. T.; POSSENTI, R. A.; LUCENAS, T. L. Aditivos em silagem de capim elefante paraíso (Pennisetum hybridum cv. paraíso). Archivos de Zootecnia, Córdoba, v. 58, p. 185-194, 2009.

FERREIRA, A. C. H.; RODRIGUEZ, N. M.; NEIVA, J. N. M.; PIMENTEL, P. G.; GOMES, S. P.; CAMPOS, W. E.; LOPES, F. C. F. Nutritional evaluation of elephant-grass silages with different levels of by-products from the cashew juice industry. Revista Brasileira de Zootecnia, Viçosa, v. 44, p. 366-376, 2015.

GONÇALVES, A. L.; LANA, R. P.; VIEIRA, R. A. M.; HENRIQUE, D. S.; MANCIO, A. B.; PEREIRA, J. C. Avaliação de sistemas de produção de caprinos leiteiros na Região Sudeste do Brasil. Revista Brasileira de Zootecnia, Viçosa, v. 37, p. 434-442, 2008.

GUIM, A.; ANDRADE, P.; ITURRINO-SCHOCKEN, R. P.; FRANCO, G. L.; RUGGIERI, A. C.; MALHEIROS, E. B. Estabilidade aeróbica de silagens de capim-elefante (Pennisetum purpureum, Schum) emurchecido e tratado com inoculante microbiano. Revista Brasileira de Zootecnia, Viçosa, v. 31, p. 2176$2185,2002$.

HAIGH, P.M. Effluent production from grass silages treated with additives and made in large-scale bunker silos. Grass and Forage Science, Malden, v. 54, p. 208-218, 1999. https://doi.org/10.1046/j.1365-

2494.1999.00172.x

JOBIM, C. C.; NUSSIO, L. G.; REIS, R. A.; SCHMIDT, P. Avanços metodológicos na avaliação da qualidade da forragem conservada. Revista Brasileira de Zootecnia, Viçosa, v. 36, p. 101-119, 2007.

KOTTEK, M.; GRIESER, J.; BECK, C.; RUDOLF, B.; RUBEL, F. World Map of the Köppen-Geiger climate classification updated. Meteorologische Zeitschrift, Suttgart, v. 15, p. 259-263, 2006.

LITTELL, R. C.; MILLIKEN, G. A.; STROUP, W. W.; WOLFINGER, R. D.; SCHABENBERGER, O. SAS ${ }^{\circledR}$ for mixed models. Cary: SAS Institute Inc, 2006. 828 p.

LOURES, D. R. S.; NUSSIO, L. G.; PAZIANI, S. F.; PEDROSO, A. F.; MARI, L. J.; RIBEIRO, J. L.; ZOPOLLATTO, M.; SCHMIDT, P.; JUNQUEIRA, M. C.; PACKER, I. U.; CAMPOS, F. P. Composição bromatológica e produção de efluente de silagens de capim-tanzânia sob efeitos do emurchecimento, do tamanho de partícula e do uso de aditivos biológicos. Revista Brasileira de Zootecnia, Viçosa, v. 34, p. 726735, 2005. https://doi.org/10.1590/s1516-35982005000300003

MCDONALD, P.; HENDERSON, A.; HERON, S. The biochemistry of silage. Marlow: Chalcombe Publications, 1991. $340 \mathrm{p}$.

PEREIRA, J. A.; AZEVEDO, A. R.; SALES, R. O.; PIMENTEL, J. C. M.; ALVES, A. A.; CASTRO, A. B. Composição química da silagem de capim-elefante cv. Napier (Pennisetum purpureum, Schum) com diferentes níveis de leucena cv. Cunningham (Leucaena leucocephala (Lam) de Wit). Revista Cientifica de Produção Animal, Areia, v. 1, p. 191-204, 1999. 
PLAYNE, M. J.; MCDONALD, P. The buffering constituents of herbage and of silage. Journal of the Science of Food and Agriculture, Malden, v. 17, p. 264-268, 1966. https://doi.org/10.1002/jsfa.2740170609

REZENDE, A. V.; GASTALDELLO JUNIOR, A. L.; VALERIANO, A. R.; CASALI, A. O.; MEDEIROS, L. T.; RODRIGUES, R. Uso de diferentes aditivos em silagem de capim-elefante. Ciência e Agrotecnologia, Lavras, v. 32, p. 281-287, 2008.

RIBEIRO, J. L.; NUSSIO, L. G.; MOURÃO, G. B.; QUEIROZ, O. C. M.; SANTOS, M.C.; SCHMIDT, P. Efeitos de absorventes de umidade e de aditivos químicos e microbianos sobre o valor nutritivo, o perfil fermentativo e as perdas em silagens de capim-marandu. Revista Brasileira de Zootecnia, Viçosa, v. 38, p. 230-239, 2009. https://doi.org/10.1590/s1516-35982009000200003

RODRIGUES, P. H. M.; BORGATTI, L. M. O.; GOMES, R. W.; PASSINI, R.; MEYER, P. M. Efeito da adição de níveis crescentes de polpa cítrica sobre a qualidade fermentativa e o valor nutritivo da silagem de capim-elefante. Revista Brasileira de Zootecnia, Viçosa, v. 34, p. 1138-1145, 2005.

https://doi.org/10.1590/s1516-35982005000400007

SANTOS, M. F. V.; GÓMEZ CASTRO, A. G.; PEREA, J. M.; GARCÍA, A.; GUIM, A.; PÉREZ HERNANDES, M. Fatores que afetam o valor nutritivo da silagens de forrageiras tropicais. Archivos de Zootecnia, Córdoba, v. 59 p. 25-43, 2010.

SILVA, J. F. C., LEÃO, M. I. Fundamentos de nutrição dos ruminantes. Piracicaba: Livroceres, 1979. 384 p.

SUGIURA, N. Further analysis of the data by Akaike's Information Criterion and the finite corrections.

Communications in Statistics - Theory and Methods, Abingdon, v. 7, p. 13-26, 1978.

TAVARES, V. B.; PINTO, J. C.; EVANGELISTA, A. R.; FIGUEIREDO, H. C. P.; ÁVILA, C. L. S.; LIMA, R. F. Efeitos da compactação, da inclusão de aditivo absorvente e do emurchecimento na composição bromatológica de silagens de capim-tanzânia. Revista Brasileira de Zootecnia, Viçosa, v. 38, p. 40-49, 2009.

TILLEY, J. M. A.; TERRY, R. A. A two-stage technique for the in vitro digestion of forage crops. Journal of the British Grassland Society, Kenilworth, v. 18, p. 104-111, 1963.

TOSI, P.; MATTOS, W. R. S.; TOSI, H.; JOBIM, C. C.; LAVEZZO, W. Avaliação do capim-elefante (Pennisetum purpureum Schum.) cultivar Taiwan A-148, ensilado com diferentes técnicas de redução de umidade. Revista Brasileira de Zootecnia, Viçosa, v. 28, p. 947-954, 1999.

VAN SOEST, P. J. Nutritional ecology of the ruminant. Ithaca: Cornell University Press ,1994. 476 p.

VAN SOEST, P. J.; ROBERTSON, J. B.; LEWIS, B. A. Methods for dietary fiber, neutral detergent fiber, and nonstarch polysaccharides in relation to animal nutrition. Journal of Dairy Science, Champaign, v. 74, p. 3583-3597, 1991. https://doi.org/10.3168/jds.S0022-0302(91)78551-2

VIEIRA, R. A. M.; CAMPOS, P. R. S. S.; SILVA, J. F. C.; TEDESCHI, L. O.; TAMY, W. P. Heterogeneity of the digestible insoluble fiber of selected forages in situ. Animal Feed Science and Technology, Amsterdan, v. 171, p. 154-166, 2012. 